\title{
BOT AND Public PRocurement: A CONCEPTUAL FRAMEWORK
}

\author{
David A. Levy*
}

\section{INTRODUCTION}

The Build-Operate-Transfer (BOT) method of project financing, ${ }^{1}$ or one of its many variants, ${ }^{2}$ has rapidly become the financial vehicle of choice for large scale infrastructure development projects. These projects, which create a public/private sector contractual relationship for a period of years, have gained global acceptance, such BOT projects having been planned or put in place in Asia, ${ }^{3}$ Africa, ${ }^{4}$ Australia, ${ }^{5}$ the Middle East ${ }^{6}$ and Indian

* David A. Levy is the Kronstein Research Fellow at the International Law Institute where he writes and lectures on international commercial law topics. He has written on the subjects of international financial leasing, foreign investment, and Bulgarian legal development. Mr. Levy is a graduate of the School of Law at Southern Methodist University and has previously worked with the State Department Office of the Assistant Legal Adviser for Private International Law on commercial law harmonization.

Acknowledgments: The author wishes to express special thanks to Professors Don Wallace, Jr. and John Linarelli of the Georgetown University Law Center, Kenneth E. Fries, General Counsel of the U.S. Trade and Development Agency, and Harold S. Burman, Esq., Executive Director of the Secretary of State's Advisory Committee on Private International Law, without whose valuable assistance this paper would not have been possible. Any errors or omissions, however, are the sole responsibility of the author.

1. A BOT project is a method of project financing in which a State identifies a need for a project that a private sector company then builds, operates for a period of time sufficient to both repay the cost of the project and provide a return on the equity investment, and then returis to the host State. A major difference in BOT and conventional development projects is that the BOT project is financed without sovereign debt. Mark Augenblick \& B. Scott Custer, Jr., The Build, Operate, and Transfer ("BOT") Approach to Infrastructure Projects in Developing Countries 3 (Aug. 1990) (unpublished monograph, on file with author). For elaboration on the BOT concept, see infra text part II.

2. Although there are a number of variations on the Build-Operate-Transfer (BOT) project financing model, this paper will use the generic term BOT to refer to the various methods, unless a particular aspect of one form is germane to the discussion. For an overview of these variations on the BOT model, see infra text accompanying note 50 .

3. Among the many BOT projects which are underway in Asia is a concession contract awarded to a consortium headed by a United Kingdom firm to operate the water system in Ipoh, Malaysia for a period of 20 years. Peter Reina, Turning on the Pressure, ENGINEERING NEws-REC., Feb. 26, 1996, at 28. BOT projects are also popular in the Philippines. See, e.g., Philippine Projects with Power Pacts Vulnerable if Secured Without Bidding, INDEP. POWER REP., Feb. 23, 1996, available in LEXIS, News Library, CURNWS File.

4. The government of the new South Africa is seeking to generate interest in BOT infrastructure projects. South African Minister to Outline BOT Opportunities, INT'L TRADE FIN., Sept. 9, 1994, available in LEXIS, World News Library, ALLWLD File.

5. A Canadian-Australian consortium recently signed a joint venture agreement to purchase and operate an electrical cogeneration plant near Adelaide, South Australia. The 
subcontinent, ${ }^{7}$ Latin America, ${ }^{8}$ Western ${ }^{9}$ and Eastern Europe, ${ }^{10}$ and North America. ${ }^{11}$ Despite the long-term nature of these partnerships, a conceptual framework which harmonizes the BOT process with sound government procurement practice has not been consistently applied. ${ }^{12}$

project will be developed on a Build-Own-Operate (BOO) basis. CU Power Nails $180-M W$ Australian Project, 14-MW London Airport Unit, INDEP. POWER REP., Aug. 11, 1995, at 3, available in LEXIS, News Library, CURNWS File.

6. For example, in the United Arab Emirates (U.A.E.), Black \& Veatch International of Kansas City is teaming with KEO International Consultants, U.A.E., to establish a BOT wastewater utility for Ajman, U.A.E. Bioremediation Market Will Have Growth of $16 \%$ a Year, AIR/WATER POLLUTION REPORT's ENVTL. WK., Jan. 26, 1996, available in LEXIS, News Library, CURNWS File.

7. Both India and Pakistan have BOT infrastructure projects planned or underway. For example, in India, a consortium of U.S. (Raytheon), Singapore, and Indian firms recently won a BOT contract to develop a new international airport in Bangalore. Indian State of Karnataka, AIRPORTS, Jan. 9, 1996, at 9. In Pakistan, a Canadian Consortium signed a $\$ 500$ million BOT contract for a 14 km, mostly elevated mass transit system in Karachi, Pakistan. Pakistan Awards BOT Mass Transit Contract, ENGINEERING NEws-REC., Jan. 22, 1996, at 3.

8. In Chile, bidding has been underway for eight separate BOT contracts for the development of the Chilean Pan-American highway project. Chile, LATiN AM. L. \& Bus. REP., Dec. 31, 1995, available in LEXIS, News Library, CURNWS File.

9. Sweden has just awarded its first BOT contract to a French-UK consortium. The 45 year concession is to build and operate a rail link between downtown Stockholm and Arlanda airport. GEC-ALSTHOM to Supply Seven Train Sets to Sweden, MONTHLY REP. ON EUR., July 25, 1995, available in LEXIS, News Library, CURNWS File. Perhaps the best known BOT project is the Channel Tunnel linking England and France. Filiberto Agusti, B.O.O. \& B.O.T. Projects 8 (unpublished manuscript, on file with author).

10. For example, in Poland, the U.S. Trade \& Development Agency recently provided $\$ 1,000,000$ to the Polish Agency for Motorway Construction and Operation to facilitate development of BOT tollroad projects. Poland: Plans for Introduction of $\$ 12,000,000,000$ Build-Operate-Transfer (BOT) Toll-Road Development Schemes, EXPORT SALES PROSPECTORREP. ON ENGINEERING CONSTRUCT \& OPERATIONS IN DEVELOPING WORLD, Jan. 1, 1996, available in LEXIS, News Library, CURNWS File.

11. The troubled Dulles Greenway toll road project in Northern Virginia was financed and constructed as a BOT project. Peter Baker \& Peter Pae, Va. May Tap U.S. Funds to Save Dulles Greenway; Plans Had Promised No Need for Public Money, WaSH. Post, Jan. 25, 1996, at B1. The Dulles Greenway represents perhaps an extreme blurring of private and public functions, with the private investment group that owns the concession having contracted to pay the Virginia State Police about $\$ 500,000$ a year for the exclusive services of eight troopers and one sergeant to patrol the toll road. The private group will also pay the costs of buying new cars, uniforms, guns, other equipment, and supplies for the troopers. Dulles Greenway Hires State Police, RoANOKE TIMEs \& WORLD NEWS, July 29, 1995, at C2. In addition, a number of highway projects in Mexico have been planned as BOT projects. Toll Road Projects, MeXICO TRADE \& L. REP., Nov. 1, 1994, available in LEXIS, News Library, CURNWS File.

12. For example, the United Nations Industrial Development Organization (UNIDO) BOT Guidelines list national laws which require public bidding of BOT infrastructure projects, but note that in practice, government negotiations with BOT bidders during the evaluation 
to a recognition that free markets, and a new understanding of rational government regulation of private enterprise, are essential for economic development and maximized societal benefit. ${ }^{24}$ The creation or reform of a system of public procurement can be an element of overall governmental reform which also includes public accountability and the separation of powers. $^{25}$

The Preamble to the UNCITRAL Model Law on Procurement of Goods, Construction and Services ${ }^{26}$ recognizes these considerations, stating as its objectives:

(a) maximizing economy and efficiency in procurement;

(b) fostering and encouraging participation in procurement proceedings by suppliers and contractors, especially where appropriate, participation by suppliers and contractors regardless of nationality, and thereby promoting international trade;

(c) promoting competition among suppliers and contractors for the supply of the goods, construction or services to be procured;

(d) providing for the fair and equitable treatment of all suppliers and contractors;

(e) promoting the integrity of, and fairness and public confidence in, the procurement process; and

(f) achieving transparency in the procedures relating to procurement

Both the UNCITRAL Model Law ${ }^{27}$ and the World Bank Guidelines ${ }^{28}$

24. Don Wallace, Jr., The Changing World of National Procurement Systems: Global Reformation, 4 PUB. Procurement L. REV. 57, 58 (1995).

25. Id. at 57, quoted in Wittig, supra note 23, at 19.

26. The UNCITRAL Model Law on Procurement of Goods, Construction and Services was developed and adopted in 1993 by UNCITRAL to "serve as a model for States for the evaluation and modernization of their procurement laws and practices and the establishment of procurement legislation where none presently exists." UNCITRAL Guide to Enactment, supra note 13, I 1 . UNCITRAL later issued a compiled revision which incorporated the procurement of services without superseding the earlier document and prepared a Guide to Enactment for the benefit of legislative drafters. Id. 11 3, 6-7.

27. In addition to conventional single stage tendering, the UNCITRAL Model Law includes procedures for alternative procurement methods, including Two-stage tendering, art. 46; Restricted tendering, art. 47; Request for proposals, art. 48; Competitive negotiation, art. 49; Request for quotations, art. 50; and where necessary, Single-source procurement, art. 51. UNCITRAL Model Law, supra note 14. The Guide to Enactment emphasizes that a State wishing to enact the Model Law as domestic law need not utilize all these alternative procedures. UNCITRAL Guide to Enactment, supra note $13, \uparrow 15$.

28. The World Bank Guidelines are designed to promote "economy and efficiency" in projects funded by the World Bank while serving as a catalyst for the development of a transparent procurement system for the Borrowing State. WORLD BANK GUIDELINES, supra note $15,11.2$. While they state a preference for international competitive bidding, other 
list various methods of formal procurement procedures, but have a preference for competitive techniques such as tendering. ${ }^{29}$ In essence, tendering is a procurement process in which competing bids are sought, received, and evaluated by the procuring entity, with the contract awarded to the party submitting the bid determined to be best according to established criteria. ${ }^{30}$ UNCITRAL characterizes tendering as "the method of procurement widely recognized as generally [the] most effective in promoting competition, economy and efficiency in procurement as well as the other objectives set forth in the Preamble [of the UNCITRAL Model Law]."31

Tendering is a system through which the government identifies a need, determines how that need may be satisfied, establishes objective criteria to select the goods which will meet that need, and then solicits bids. ${ }^{32}$ In the case of services, the most common procurement method is the request for proposals (RFP) ${ }^{33}$ In order to achieve the good-government goals of transparency and competition, the bid solicitation must be publicized, the selection criteria must be disclosed and quantifiable to the maximum extent possible, and the award of the contract must be made openly and be available as a public record. ${ }^{34}$ Tendering may be either single stage, where the procurement is relatively straightforward (such as the purchase of a

procurement procedures listed include: Limited International Bidding, 13.2 ; National Competitive Bidding, 1 3.3; Shopping (request for quotations), 1 3.5; Direct Contracting, I 3.7; Force Account (construction by the borrower's own personnel), 9 3.8; Procurement Agents (United Nations agencies act as procurement agents), 1 3.9. Id.

29. The UNCITRAL Model Law treats tendering as the primary method of procurement of goods and construction. UNCITRAL Model Law, supra note 14, art. 18(1). The World Bank expresses a strong preference for international competitive bidding in the projects which it funds. WORLD BANK GUIDELINES, supra note $15,91.3$.

30. Gosta Westring, International Procurement: A Training Manual 27 (1990).

31. UNCITRAL Guide to Enactment, supra note 13, 914.

32. See generally UNCITRAL Guide to Enactment, supra note 13, I 16 (discussing elements of tendering).

33. See UNCITRAL Model Law, supra note 14, ch. IV ("Principal Method for Procurement of Services"). Under the UNCITRAL Model Law, the RFP mechanism includes many of the procedures which promote sound procurement practices in tendering, such as "unrestricted solicitation of suppliers and contractors as the general rule, and predisclosure in the request for proposals of the criteria for evaluation of proposals and predisclosure of the selection procedure . . . ." UNCITRAL Guide to Enactment, supra note 13, 117.

34. An additional good-government practice mandated by the UNCITRAL Model Law is the requirement that all procurement contract awards be published. This promotes transparency and public confidence in the government. UNCITRAL Model Law, supra note 14, art. 14; see also UNCITRAL Guide to Enactment, supra note 13, art. 14(1). The goal of transparency in procurement practice would support advertising even if single source procurement were utilized, such as when it is necessary to obtain spare parts for existing machinery. 
commodity), or in two stages, where the initial solicitation seeks alternative responses to the perceived need while the second stage builds on the submitted proposals to present a narrower and much more quantifiable set of evaluation criteria. ${ }^{35}$ A key to the good-government aspect of public procurement is that the bidding process must be legitimate, with no further negotiation after a bid is tendered.

Given the scale of most international projects, both the World Bank Guidelines $^{36}$ and UNCITRAL Model Law ${ }^{37}$ allow prequalification of bidders. Prequalification of bidders seeks to establish that the bidders will be able to perform the contract if it is awarded to them and makes for better bidding by eliminating those bidders who are incapable of performing the contract satisfactorily-thereby increasing the confidence of qualified bidders that an award will not be given to an inexperienced bidder who has made an unrealistic bid. ${ }^{38}$ The criteria used for prequalification must be objective and be related to the ability of the bidder to perform the contract. ${ }^{39}$ For example, the World Bank Guidelines state that "[p]requalification shall be based entirely upon the capability and resources of prospective bidders to perform the particular contract satisfactorily, taking into account their (I) experience and past performance on similar contracts, (ii) capabilities with respect to personnel, equipment, and construction or manufacturing facilities, and (iii) financial position." ${ }^{20}$ Prequalification also promotes economic efficiency in the overall procurement process by minimizing the cost to the host State of evaluating unqualified bids. ${ }^{41}$

35. For example, in a two stage system under the UNCITRAL Model Law, the first stage seeks initial tenders without a tender price. These tenders may present "proposals relating to the technical, quality or other characteristics of the goods, construction or services as well as to contractual terms." The procuring entity then establishes a final form for the second stage "with prices with respect to a single set of specifications." UNCITRAL Model Law, supra note 14 , art. 46.

36. The World Bank notes that prequalification is generally required for large scale or technical projects, or where "the high costs of preparing detailed bids could discourage competition, such as custom-designed equipment, . . specialized services, . . . or management contracting." WORLD BANK GUIDELINES, supra note 15, 12.9 .

37. The UNCITRAL Model Law provides that all bidders must be qualified either prior to tendering their bids or at a later stage in order to participate in the procurement process. UNCITRAL Model Law, supra note 14, art. 6(1)(b).

38. World Bank, Standard PREQUalification Documents: Procurement of WORKS, Annex 1 5, 6 (1993).

39. Subject to limited exceptions (such as those regarding compliance with United Nations economic sanctions, government trading restrictions, or firms which have been involved in the planning of a project, inter alia), the World Bank does not permit a borrower to deny prequalification to a firm "for reasons unrelated to its capability and resources to successfully perform the contract." WORLD BANK GUIDELINES, supra note $15,91.7$.

40. Id. \2.9.

41. A possible danger of prequalification, or reliance on lists of prequalified bidders in tendering, is the risk of insularity which would limit rather than promote competition. 


\section{BOT (BUILD-OPERATE-TRANSFER) CONTRACTS}

\section{A. BOT Defined}

The $\mathrm{BOT}^{42}$ project financing mechanism is a true hybrid, representing an intermediate stage between traditional state monopolies and private enterprise. ${ }^{43}$ BOT represents a long-term interrelationship of the government and private sector. ${ }^{44}$ In a BOT project, either the government $t^{45}$ or a private entity ${ }^{46}$ identifies a need for a development project. The government then grants a concession ${ }^{47}$ to a private sector enterprise to build the project and operate it for a fixed period of years after which time the project is transferred to the host State. ${ }^{48}$ The revenue derived from the project allows the private investors to recover their costs and realize a profit over the life of the concession period. ${ }^{49}$ Other project structures, such as Build-OperateOwn (BOOs), Build-Transfer-Operate (BTOs), Build-Lease-Transfer (BLTs), and Build-Own-Operate-Transfer (BOOTs), are variations on this theme..$^{50}$ "Conversely, Rehabilitate-Operate-Transfer projects (ROTs) relate to taking

42. The BOT concept was first articulated by the Prime Minister of Turkey, Turgut Ozal, in the early 1980 s in relation to Turkey's privatization efforts. Augenblick \& Custer, supra note 1 , at 2 . For a discussion of the difficulties encountered in pursuing BOT projects in Turkey, see John Barham, Survey of Turkey, FIN. TIMES, June 12, 1995, at 4.

43. BOT can be conceptualized as a midpoint on the continuum between state monopolies and the pure free market, and may help to introduce free market concepts to a transitional society. The UNCITRAL Guide to Enactment states that "reform of the public procurement system is a cornerstone of the law reforms being undertaken [in transitional economies] to increase the market orientation of the economy." UNCITRAL Guide to Enactment, supra note 13,93 . For a pictorial representation of this private enterprise continuum, see infra Appendix.

44. The concession period in BOT projects typically ranges from 15 to 30 years for a power plant to 50 years for a major project such as the Channel Tunnel. Agusti, supra note 9 , at 8 .

45. The government will identify the need for a project and then will typically do a feasibility study to determine if the revenues from the project will support BOT project financing. See UNIDO BOT GUIDELINES, supra note 12 , at 21 . These feasibility studies are often funded by bilateral and multilateral aid agencies. Id.

46. For example, the Hong Kong Harbour Tunnel project was in response to an unsolicited proposal from a developer. Id. at 121.

47. A concession is a grant of a franchise by the State to the private project company of the State's monopoly power to build and operate a project. Id. at 3 .

48. At the end of the concession period, the host State may also choose to issue a new concession for continuing operation of the project, either to the initial private sector developer or to an entirely new group. Id. at 275 .

49. Thomas M. Kerr, Supplying Water Infrastructure to Developing Countries via Private Sector Project Financing, 8 GEO. INT'L ENVTL. L. REv. 91,93 (1995).

50. UNIDO BOT GUIDELINES, supra note 12, at 3. 
over of an existing asset by the private developers for rehabilitation or upgrading, followed by commercial operation." 51 The ROT form would be of particular utility in places with a deteriorating infrastructure such as Eastern Europe or the District of Columbia. BOO is a step closer to the free market ideal in that the private sector is retaining ownership rather than transferring the project back to the state. Many investors argue that $\mathrm{BOO}$ represents a longer-term commitment to private enterprise. ${ }^{52}$

Through BOT, the host State is able to gain an economic asset without government spending while maintaining a measure of regulatory control over the project..$^{53}$ BOT permits the host State to use private sector debt to fund public infrastructure development. ${ }^{54}$ It is widely asserted that private sector developers have a stronger profit incentive to complete infrastructure projects on time and operate them more efficiently than does a traditional state-owned enterprise..$^{55}$ An additional good-government benefit of the public/private partnership is that the government has a benchmark ${ }^{56}$ which it may observe and which it can learn effective management and operational techniques from private (and largely foreign) experts. The government can transfer the principles underlying these techniques to other sectors and future infrastructure projects. ${ }^{57}$

Two factors identified as crucial for the success of a BOT project are (1) "a critical need for the project" and (2) "a near-monopoly situation in the provision of a service or product." 58 Because of the ongoing relationship between the government and the private sector in a BOT project, there must be strong governmental commitment to the project. ${ }^{59}$ Throughout the life of the BOT project, from planning to construction, operation, and oversight, the host State gains valuable regulatory experience. Ongoing supervision of the project by the host State during the construction and operation phases is essential ${ }^{60}$ given that the State always has a vested reversionary interest in a

51. Martin Stewart-Smith, Private Financing and Infrastructure Provision in Emerging Markets, 26 L. \& POL'Y INT'L Bus. 987 n.19 (1995).

52. Agusti, supra note 9, at 4. Functionally, because in a Build-Operate-Own (BOO) project there is no obligation to transfer the project back to the host State, it may be seen as a contractual consent to a form of long-term regulation of the enterprises. See infra Appendix.

53. Kerr, supra note 49 , at 99.

54. Agusti, supra note 9, at 3.

55. Kerr, supra note 49, at 101.

56. See UNIDO BOT GUIDELINES, supra note 12 , at 7.

57. Jonathan M. Pertchik, The Build, Operate and Transfer Approach to Infrastructure Development in Mexico, 4 PUB. Procurement L. REv. 168, 177 (1995).

58. Robert Tiong, The Structuring of Build-Operate-Transfer Construction Projects 4, 5 (1991) (monograph on file with author).

59. Pertchik, supra note 57, at 172.

60. See UNIDO BOT GUIDELINES, supra note 12, at 247-71. 
true BOT project. ${ }^{61}$

The continued regulation of the project is important for both the commercial success of the project and the public good because it prevents the project operators from abusing a grant of monopoly power. ${ }^{62}$ Pricing a basic product such as electricity or clean water out of the reach of the citizenry will quickly undermine popular support for privatization in developing countries. On the other hand, the revenues must be sufficient to compensate lenders and investors who have made the project possible ${ }^{63}$

Just as a BOT project requires from a host State a long-term commitment to the project and its private sector partner, the private sector partner must plan for the long term viability of the project to assure economic success and popular support for the life of the public/private partnership. ${ }^{64}$ It is critical that the potential private sector participant compile accurate financial and economic data to determine the feasibility of the project. ${ }^{65}$ While the compilation of such information is costly and time consuming, ${ }^{66}$ it is essential that the data be accurate so that the support of financial institutions and investors may be gained, ${ }^{67}$ and the cash-flow problems associated with inaccurate or overly optimistic projections may be avoided. ${ }^{68}$

\section{B. BOT and Infrastructure Development}

BOT is well suited to large scale infrastructure projects such as highway construction. ${ }^{69}$ It benefits those governments which need highways

61. See Tiong, supra note 58 , at 16.

62. Agusti, supra note 9, at 4 . As a practical matter, the rates for the project are established contractually and typically are either fixed or have some form of escalator clause. See UNIDO BOT GUIDELINES, supra note 12, at 109.

63. Tiong, supra note 58 , at 6 .

64. For an interesting discussion of the mechanics of BOT project planning, see Augenblick \& Custer, supra note 1.

65. Tiong, supra note 58 , at 7 .

66. For example, the Japanese company Kumagai Gumi is reported to have spent approximately $\$ 5$ million in pre-signing costs on a Bangkok toll road BOT project. Augenblick \& Custer, supra note 1 , at 8 . Kumagai later withdrew from the project after the government failed to deliver land for the right of way on a timely basis and cut user tolls. Paul Handley, Bitterly, Kumagai Gumi Bows Out of the Bangkok Expressway, InSTITUTIONAL INVESTOR, Apr. 1994, at 21.

67. Tiong, supra note 58 , at 7 .

68. See, e.g., Peter Pae, Drivers Put the Brake on Toll Road's Promise; Investors in Dulles Greenway Try to Steer the Failing Project Back on Course, WASH. POST, Dec. 26, 1995 , at Al (inaccurate highway use projections based on dated traffic study and failure to properly assess demographics contributed to toll road utilization shortfall of approximately $66 \%$ and threatened financial stability of the project).

69. For an interesting discussion of the economic efficiency of BOT infrastructure 
to link their markets and which cannot either afford the work or must give priority to other projects. BOT also benefits the private sector which gains the profits generated during the operating concession phase. ${ }^{70}$ Moreover, commercial banks may be more willing to make loans to a private project company to finance the project than they would be to loan money directly to the government. ${ }^{71}$ This may reflect the common belief that a private enterprise will have greater incentive to build and operate the project with greater efficiency, as well as to circumvent local graft and corruption. ${ }^{2}$ Avoiding reliance on sovereign debt permits infrastructure development to occur more rapidly without creating a drain on other sectors of the economy. ${ }^{73}$

BOT is not confined to developing countries. In the United States, the Dulles Greenway toll road was financed by an international consortium including American insurance companies and private European banks. ${ }^{74}$ In Europe, the Channel Tunnel linking Great Britain and France was financed and constructed as a BOT project. ${ }^{75}$ In fact, the Intermodal Surface Transportation Efficiency Act of $1991^{76}$ encourages state governments to use private capital and direct user payments in the form of tolls to increase investment in the U.S. highway system. ${ }^{7}$

The typical infrastructure project requires so much capital, expertise, and long-term commitment that there are only a limited number of companies or joint ventures which have the capability to complete a BOT project. ${ }^{78}$ While this small number might suggest sole source procurement or limited "list" bidding, ${ }^{79}$ a commitment to good-government argues strongly for some form of regulated procurement such as prequalified tendering or request for proposals. ${ }^{80}$ This transparency promotes public confidence in the enterprise and minimizes charges of corruption-real or perceived-which may arise when a government enters into a long term relationship with a single private enterprise for a valuable concession.

projects, see John B. Miller, Using Competition to Stimulate Investment in Public Infrastructure, 31 PROCUREMENT L. 1 (Spring 1996).

70. Bankrolling the Roadbuilders, WORLD HIGHWAYS/ROUTES DU MONDE 31, 32 (May/June 1994).

71. Pertchik, supra note 57, at 176.

72. UNIDO BOT GUIDELINES, supra note 12 , at 6-8.

73. Id. at 32-33.

74. Bankrolling the Roadbuilders, supra note 70 , at 31.

75. Pertchik, supra note 57, at 173.

76. 23 U.S.C. $\$ 129$ (1995).

77. Bankrolling the Roadbuilders, supra note 70 , at 31.

78. Pertchik, supra note 57, at 179.

79. See UNIDO BOT GUIDELINES, supra note 12, at 103, 111.

80. Pertchik, supra note 57 , at $\mathbf{1 7 9 - 8 0}$. 


\section{Current BOT Practice}

While BOT projects must rely on a legal framework-including well defined contractual and property rights ${ }^{81}-$ which facilitates private investment, BOT and other privately funded infrastructure projects may not currently be subject to the procurement laws or foreign investment laws of a host State. ${ }^{82}$ For example, the procurement regulations of Indonesia do not govern privately funded projects. ${ }^{83}$ On the other hand, the Foreign Investment Law of Vietnam was amended in 1992 to permit BOT projects, and regulations were promulgated in 1993 to govern the BOT process. ${ }^{84}$

For BOT projects, the World Bank Guidelines provide for selection of the private sector participant through either international competitive bidding or what it terms "limited international bidding"-a situation in which bids are solicited from lists without advertised solicitation. These methods may include several stages to arrive at an "optimal combination" of evaluation criteria for the final solicitation. These criteria include "the cost and magnitude of the financing offered, the performance specifications of the facilities offered, the cost charged to the user or purchaser, other income generated for the borrower or purchaser by the facility, and the facility's depreciation." ${ }^{85}$ Once the private sector participant is selected, it is free to procure the goods, services or construction required for the project as it sees fit. $^{86}$

Currently, host States seeking BOT investment may either identify a particular development objective and in some form publicize the need for development ${ }^{87}$ in order to seek proposals, or they may be approached by a particular international consortium which has experience in a market and proposes to enter into a BOT project. ${ }^{88}$ The latter may appear efficient given

81. See Augenblick \& Custer, supra note 1, at 30.

82. For a foreign investment law model that addresses BOT, see DON WALLACE ET AL., MODEL FOREIGN INVESTMENT LAW ANNOTATED ch. 1.3 \& cmt. 3 (1996).

83. Sullivan, supra note 21 , at 2.

84. James S. Finch \& Sesto E. Vecchi, BOT Contracts in Vietnam: Regulations and Guidance, E. ASIAN EXECUTIVE REP., Mar. 15, 1995, at 6. See also Mathilde L. Genovese, Succeeding in Vietnam's Emerging Market Economy, E. ASIAN EXECUTIVE REP., May 15, 1995, at 7. See the UNIDO BOT GUIDELINES for a list of laws of various governments which affect BOT projects. UNIDO BOT GUIDELINES, supra note 12, at 100 .

85. WORLD BANK GUIDELINES, supra note 15, $13.13(\mathrm{a})$.

86. Id. \ 3.2.

87. For example, the Asian Development Bank posts BOT opportunities on the Internet, such as the Kabirwala Power project in Pakistan, which is to be structured as a BOO project. See Project Profiles for Commercial Co-Financing, Asian Development Bank Business Opportunities homepage < http://www.asiandevbank.org/adbbo/adbbo.html > .

88. See generally Robert Tiong, An Interview with Gordon Wu, in The Structuring of Build-Operate-Transfer Construction Projects 46 app. (1991) (monograph on file with author) (discussing the strategy of Hopewell Holding, a Hong-Kong based company with extensive 
the limited number of bidders capable of building and operating a large BOT project (such as the construction and operation of a hydroelectric dam) and the limited experience of many host States in public procurement and BOT project negotiation. But the reliance on a single proposal from a single bidder, no matter how capable or honest the transaction might be, invites allegations of corruption and a lack of commitment to the free market.

As part of the concession package offered by the host State, the government may contractually grant a certain number of guarantees to the private sector participant. Such guarantees of profitability may include "take or pay" clauses in the concession agreements whereby the State agrees to pay for a fixed amount of the product of the BOT project, regardless of whether or not it chooses to accept actual delivery or use of the service or product ${ }^{89}$ Care should be taken that these guarantees are not excessive, otherwise the net result is the shifting of the commercial risk back to the public sector. ${ }^{90}$

Other forms of guarantees, which expose the host State to contractual contingent liability throughout the term of the concession, may include guarantees to repay loans used for financing the project in the event of default by the private sector parties and agreements regarding currency fluctuations and force majeure..$^{91}$ Given the long period of private/public involvement, political risk of government instability may be dealt with contractually through guarantees ${ }^{92}$ or through investment insurance made available through the Multilateral Investment Guarantee Agency (MIGA) of the World Bank $^{93}$ or the United States Overseas Private Investment Corporation (OPIC).$^{94}$ Two essential guarantees for the private sector participant are an assurance of its ability to repatriate currency rather than to have to rely on a countertrade arrangement ${ }^{95}$ and a dispute settlement mechanism, such as arbitration under the UNCITRAL rules ${ }^{96}$ or the International Centre for Settlement of Investment Disputes (ICSID). ${ }^{97}$

experience in initiating and participating in BOT projects in Asia).

89. Kerr, supra note 49 , at 105-06.

90. Id. at 106.

91. Sullivan, supra note 21 , at 3. For example, the $\$ 4.5$ billion Bandar Khomeni petrochemical complex in Iraq was abandoned due to Iraqi air raids during the Iran-Iraq war, causing Mitsui Bank of Japan to take a $\$ 1$ billion write-off in 1987 . Tiong, supra note 58, at 29.

92. Pertchik, supra note 57, at 174 .

93. MIGA insurance coverage includes risks associated with currency conversion and transferability, expropriation, armed conflict, politically motivated sabotage, and breach of contract by the host State. See UNIDO BOT GUIDELINES, supra note 12, at 206.

94. RALPH H. FOLSOM ET AL., INTERNATIONAL BUSINESS TRANSACTIONS IN A NUTSHELL 436-38 (4th ed. 1992).

95. See UNCITRAL LEgal Guide on International Countertrade TransaCtions, U.N. Doc. A/CN.9/Ser.B/3 (1993).

96. Arbitration Rules of the United Nations Commission on International Trade Law.

97. Convention on the Settlement of Investment Disputes between States and Nationals 
Nevertheless, the more guarantees a government extends to the private sector parties in a BOT transaction, the less the project resembles the private enterprise ideal.

\section{BOT WITHIN THE PROCUREMENT CONTEXT}

As noted above, BOT contracts have not been consistently viewed as a component of the overall procurement process. ${ }^{98}$ The World Bank Guidelines, although they attempt to provide a competitive format through which BOT projects are to be awarded, allow for the use of "limited international tendering"-a process which relies on established bidder lists with no bid advertisement and which substantially defeats the goal of openness and transparency that should be the driving force behind a good government's procurement practice. ${ }^{99}$ Moreover, BOT does not fit easily into the structures proposed in the UNCITRAL Model Law. ${ }^{100}$ Simple requests for proposals, while an improvement on a single source negotiation, may be difficult to reconcile with the desired transparency. ${ }^{101}$

A good-government model for the facilitation of BOT projects may be constructed which is consistent with sound procurement practices and the recognized superiority of tendering as the preferred method of procurement. ${ }^{102}$ First, the host State should identify the necessary infrastructure project and conduct a feasibility study to determine whether the project is viable in light of the conditions which are consistent with a successful BOT project. ${ }^{103}$ After determining the potential scope of the project, the host State should compile a project profile, advertise the potential project, and seek to pre-qualify prospective bidders. ${ }^{104}$ The bidders should then submit proposals which offer solutions to the problem that the

of Other States, and Accompanying Repon of the Executive Directors of the International Bank for Reconstruction and Development, Doc. ICSID/2.

98. SeeUNIDO BOT GUIDELINES, supra note 12, at 100-01 (listing procurement laws).

For an example of an article which attempts to view BOT in the procurement context, see Pertchik, supra note 57, at 183.

99. See supra text accompanying note 85 .

100. UNCITRAL Model Law, supra note 14.

101. The UNCITRAL Guide to Enactment recognizes this problem, stating that "from the standpoint of transparency, competition and objectivity in the selection process, two-stage tendering and request for proposals are likely to offer more than competitive negotiation, with its high degree of flexibility and possibly higher risk of corruption." UNCITRAL Guide to Enactment, supra note 13, at $26 \mathrm{cmt}$. 19(1).

102. The proposed method builds on the procurement strategies outlined in Chapter 6 of the UNIDO BOT GUIDELINES, supra note 12 and the two-stage tendering method of article 46 of the UNCITRAL Model Law, supra note 14.

103. Tiong, supra note 58 , at 5 .

104. For a discussion of the utility of prequalification, see UNIDO BOT GUIDELINES, supra note 12 , at 110-12. 
This paper begins by considering the public procurement process, in particular by focusing on the good-government aspects of public procurement, ${ }^{13}$ and discusses the procurement structures proposed by the United Nations Commission on International Trade Law (UNCITRAL) Model Law on the Procurement of Goods, Construction and Services ${ }^{14}$ and the World Bank Guidelines for Procurement Under IBRD Loans and IDA Credits $^{15}$ as models for framing a BOT procurement. Part II will examine the BOT method of project financing, its use in large scale infrastructure development, and the role of BOT in economic development. Finally, part III will consider BOT within the context of regulated public procurement and will make a modest proposal for a conceptual framework for BOT which is consistent with the good-government practices that a modern system of public procurement seeks to further. ${ }^{16}$

phase are not uncommon. UNIDO, GUIDELINES FOR THE DEVELOPMENT, NEGOTIATION AND Contracting of Build-Operate-Transfer (BOT) Projects 100, 103, 117 (1995 PrePrint) [hereinafter UNIDO BOT GUIDELINES]. In addition, the Guidelines endorse the concept of submission of unstructured alternative bids in order to encourage innovation by bidders. Id. at 116. It is arguable that, unless these alternatives are considered before a final, structured bid solicitation is made available to qualified bidders, the procuring entity within the host State will be in a discretionary position of evaluating disparate bids, which is inconsistent with sound procurement practice.

13. A sound public procurement law promotes good-government ideals by encouraging confidence that the government will act responsibly in its purchases, by seeking the optimum value for public funds in an atmosphere of accountability, and by allowing fair competition through regularized, transparent practices. See UNCITRAL Guide to Enactment of UNCITRAL Model Law on Procurement of Goods, Construction and Services, U.N. Commission on International Trade Law, 27th Sess., I 8, U.N. Doc. A/CN.9/403 (1994), [hereinafter UNCITRAL Guide to Enactment].

14. UNCITRAL Model Law on Procurement of Goods, Construction and Services, Official Records of the General Assembly, U.N. Commission on International Trade Law, 49th Sess., Supp. No. 17, Annex I, U.N. Doc. A/49/17 (1994), thereinafter UNCITRAL Model Law]. UNCITRAL also drafted a guide to enactment of the Model Law to assist States in formulating a modern public procurement law. UNCITRAL Guide to Enactment, supra note 13.

15. World Bank, Guidelines: Procurement Under IBRD LoANS AND IDA CREDITS (5th ed. 1995), [hereinafter WORLD BANK GUIDELINES]. It is interesting that the World Bank is taking an increasing interest in BOT projects and is reported to be planning to have its International Finance Corp. private sector arm take equity positions in BOT projects. Frank Gray, FT Exporter, FinANCIAL Times, Jan. 31, 1995, at XX.

16. The BOT project form is a major topic of study for UNCITRAL, which is currently engaged in the drafting of a legislative guide for BOT. See generally Build-Operate-Transfer projects (BOT): Draft materials for a legislative guide, U.N. Doc. LA/TL/BOT/Paper (1996) (internal discussion paper prepared by the UNCITRAL Secretariat for an expert group meeting on BOT, held in Vienna, 2-4 Oct. 1996). See also Possible Future Work: Build-OperateTransfer Projects: Note by the Secretariat. U.N. Committee on International Trade Law, 29th Sess., 11 1-3, U.N. Doc. A/CN.9/424 (1996); Report of UNCITRAL on the work of its twentyninth session, 19 225-30, U.N. Doc. A/51/17 (1996).

In addition, an international conference on legal aspects of BOT contracts, sponsored 


\section{Public Procurement: Policy and Practice}

The procurement of goods or services by a government is an important factor in the economic vitality of states and has drawn the attention of international inter-governmental organizations such as the World Bank ${ }^{17}$ and UNCITRAL. ${ }^{18}$ Sound procurement practice is particularly important in those developing countries and states the economies of which are in transition because of the substantial role that government purchasing plays in the entire economy. ${ }^{19}$ In particular, procurement which strengthens a nation's infrastructure facilitates indigenous business and contributes to the social welfare of the society. ${ }^{20}$ Thus, implementation of regularized and transparent procurement practices is important in providing goods and services to the public at a reasonable $\operatorname{cost}^{21}$ and in promoting confidence in government by establishing a discipline which deters corruption ${ }^{22}$ or arbitrary decisions by limiting unfettered discretion by purchasing officials. Indeed, corruption not only harms the public in that the end product or service is not necessarily the best that the market has to offer but also harms the contractor by lessening the incentive to provide a fully competitive product or service. ${ }^{23}$

A focus on procurement policy is particularly timely. The fall of communism in 1989 and the recent lessening of the North/South distrust-a distrust which had driven the New International Economic Order-has led

by UNCITRAL, the International Law Institute (I.L.I.), and the Cairo Regional Centre for International Commercial Arbitration, was held in Cairo on October 21-24, 1996.

17. See, e.g., WORLD BANK GUIDELINES, supra note 15.

18. See UNCITRAL Model Law, supra note 14; UNCITRAL Guide to Enactment, supra note 13 .

19. UNCITRAL Guide to Enactment, supra note 13, \ 3.

20. Among the many benefits associated with infrastructure investment are the promotion of industrial growth through the provision of a basic service, increased employment, reduced costs to consumers, and increased land values in areas surrounding the project. See UNIDO BOT GUIDELINES, supra note 12, at 31-32.

21. Hal Sullivan, Issues Concerning Government Procurement Regulations and PublicPrivate Partnerships 6 (Nov. 6, 1995) (manuscript on file with author).

22. For a thorough discussion of corruption issues in Italian public procurement, see Enzo Pontarollo, Regulatory Aspects and the Problem of Corruption in Public Procurement in Italy, 5 PUB. PROCUREMENT L. REV. 201 (1995). For a discussion of the corruption issues generally in the People's Republic of China, see John Linarelli, China and the GATT Agreement on Government Procurement, 8 J. CHINESE L. 185, 212-13 (1994). For an interesting discussion of corruption issues worldwide, see Internet Corruption Ranking, Transparency International homepage < http://www.gwdg.de/ uwvw/icr.htm > .

23. Wayne A. Wittig, The Essence of Public Procurement for the Post-Communist World, ConT. MGMT., Mar. 1993, at 18, 22. For an interesting discussion of the costs of official corruption, see Mark J. Murphy, International Bribery: An Example of an Unfair Trade Practice?, 21 BROOK. J. INT'L L. 385 (1995). 
project seeks to address. Elements of the proposals would be reconciled, and a final model would be developed, with a point system which assigns points for each aspect of the bid on the basis of objective, quantifiable criteria. ${ }^{105}$ This model would then be submitted to the bidders for their use in submitting a second stage bid. The bid which is then most responsive to the solicitation-with the highest number of points-should be awarded the BOT contract. ${ }^{106}$

\section{CONCLUSION}

The Build-Operate-Transfer model of project financing will increasingly become the preferred instrument of infrastructure development in the free market of the 21st century. The good-government goals which are part and parcel of sound procurement practice-transparency, openness, and market access-are equally, and arguably to a greater extent, applicable in the BOT context given the long-term public/private relationship of the typical BOT infrastructure project and the public good which is served by infrastructure investment. The North/South animosity with its charges of neo-colonialism which fueled much of the developmental dialogue of the late 20 th century will be less likely to attach to the BOT projects of the future which are awarded in a manner which is consistent with these good government goals and economic development will continue to benefit both the developing and developed world.

105. The use of preliminary proposals to refine a final set of bid criteria is being used by the Department of Energy in the procurement of a new particle accelerator for a project led by Los Alamos. See Tritium Production Request Drafted, DEF. Cleanup, Dec. 8, 1995 , available in LEXIS, News Library, CURNWS File.

106. See Pertchik, supra note 57, at 183. 

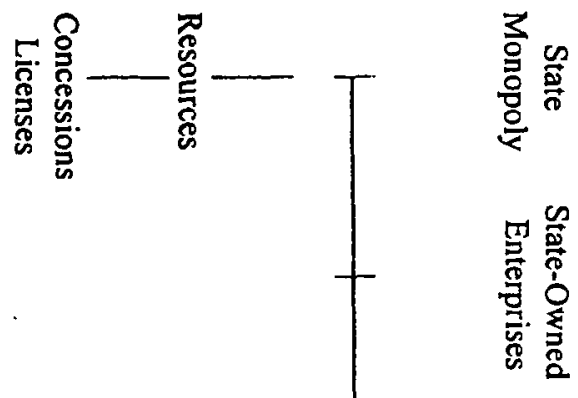

总一离-

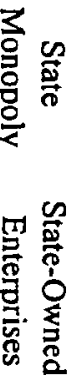

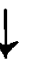

20

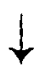

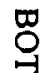

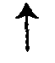

㿣

営
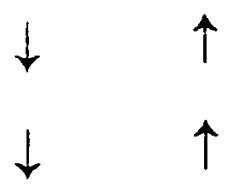

$\uparrow$

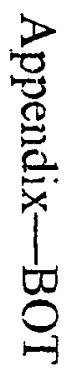

$\downarrow$

$\uparrow$

芑
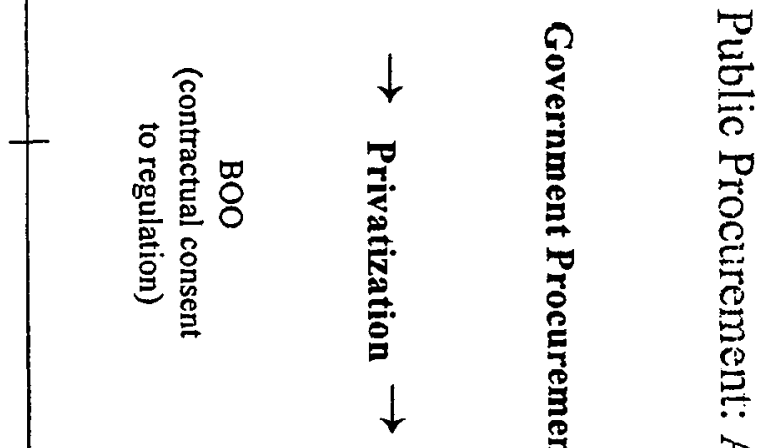

蛋

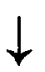

D

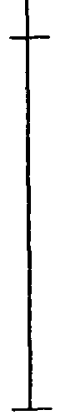

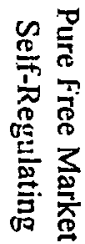

$\downarrow$

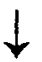

2
0
0
0
0
0
0
0
0
0
0
0
0
0
0
0

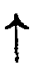

$\downarrow$

2
0
0
0
0
0
0
0
0
0
0
0
0
0

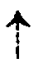

$\downarrow$

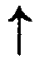

